\title{
SYSTEMATIC LITERATURE REVIEW: THE ROLE OF GOVERNMENT INSTITUTIONS IN CORPORATE SOCIAL RESPONSIBILITY IN NIGERIA.
}

\author{
Abubakar Isah Hassan* \\ Department of Public Administrative Studies and Politics \\ University of Malaya, Kuala Lumpur50603 \\ Malaysia. \\ isaabubakar30@gmail.com

\section{Norma Binti Mansor} \\ Department of Public Administrative Studies and Politics \\ University of Malaya, Kuala Lumpur50603 \\ Malaysia. \\ norma@um.edu.my

\section{Nurhidayah Binti Abdullah} \\ Department of Public Administrative Studies and Politics \\ University of Malaya, Kuala Lumpur50603 \\ Malaysia. \\ abd_hidayah@um.edu.my
}

*Corrosponding author's Email: isaabubakar30@ gmail.com

Peer-review under responsibility of 4th Asia International Multidisciplinary Conference 2020 Scientific Committee http://connectingasia.org/scientific-committee/

(C) 2020 Published by Readers Insight Publisher, lat 306 Savoy Residencia, Block 3 F11/1,44000 Islamabad. Pakistan, editor@readersinsight.net 


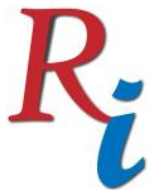

\section{Asia Proceedings of Social Sciences (APSS) \\ www.readersinsight.net/APSS}

\section{A b s t r a c t}

Although Corporate Social Responsibility (CSR) initiatives have advanced considerably in the past few years. Despite the advancement in the literature on (CSR) very few of them have reflected on the roles of government institutions, especially in the emerging nations. The purpose of the review is to provide a systematic analysis of the role of government institutions on CSR. A methodical kind of literature review was carried out utilising approaches proclaimed by the Institute for Analyses and Propagations but adjusted to the specific requirements of this analysis. The various online database was searched. The search phrases used were governments, CSR, Civil society organisation (CSOs). The review studies are selected from 2009-2019. The total number of articles collected is one hundred and twenty-three (123) out of which sixty (60) of them were found worthy for the analysis. The functions of government institutions were recognised, particularly in the setting of facility deliverance and sustainable development, all together were described to be used to government institutions, CSR and CSOs research, and other activities. The functions described in the piece of work ought to enlighten all researchers in CSR that successful research in CSR cannot be realised without involving institutional theory.

Keywords: Government institutions, Corporate Social Responsibility, and Civil Society Organisations in Nigeria.

\section{Research Objectives}

The concept and practices of CSR are progressively entrenched and are currently gaining significant momentum from corporate managers, governments and scholars. This is evidenced in the growing number of scholarly kinds of literature on the theoretical and practical features of CSR as well as in the expanding number of corporations embracing CSR in their policies. In recent times, CSR has progressively attracted governments' interest and is now advocated in public policy, especially in the European Union (EU). This review adopted the tenets of Institutional theory to review the role different organisations perform on the advancement of CSR initiatives.

A study of the recent literature shows that the delicate method of CSR strategies agrees with a broader development of public administration overall, that takes a step from ordered rule to more network-like and associating methods of self- and co-rule. According to (Matten and Moon, 2020), "CSR is not a feature of the new worldwide corporation but is also gradually a feature of new societal governance".

This review shows logical literature undertaken on the role of government institutions in CSR. (Sepúlveda et al., 2019) describe some motives for engaging in logical analysis, the most common is to find any openings in the present investigation so that suggestions can be made 


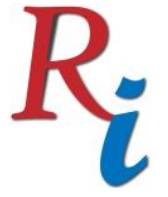

\section{Asia Proceedings of Social Sciences}

(APSS)

www.readersinsight.net/APSS

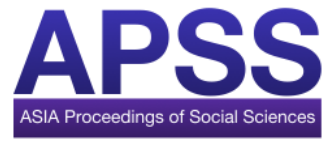

in respect of areas for advance research, and to produce a background/experience to suitably place new findings actions.

The global view is that CSR was 'traded' into emerging nations through multinational corporations (MNCs), whose centre of operations is established in western countries particularly America and Europe (Uzo and Shittu, 2019).

\section{Methodology}

The methodical literature review was directed utilising strategies declared by the Institute for Analyses and Dissemination (2009) but adjusted to the specific desires of this analysis. A review strategy clarifies the strategy receives within the review covering choices approximately incorporation standards, research procedure, research choice, information extraction, quality evaluation, as well as information union. A research procedure was guided from February to April 2019.

The undermentioned catalogues were searched: Emerald, Sage, Oxford Cambridge, Harvard, Taylor, and Francis online, Scopus, and expanded to Google Scholar, Web of Science, Springer Link, Science Direct, Wiley Online Library. Each article recovered in the first stage was examined founded on the title; watchwords with the article that tended to "CSR" are distinguished as possibly important. For incorporation, a paper ought to incorporate a substantial depiction of the recognised part or performed actively in CSR activities.

This implies that the paper should incorporate points of interest on the impact of the government institution. Common limitations were that papers ought to be composed in English and ought to be on the role of government. Overall, 123 papers were gotten and 6o maintained relevant after copies were expelled. Three primary topics, all alluding to roles of government were recognised. The topics are. The role of the government, CSR and CSOs.

\section{Results}

(Arli and Lasmono, 2010) revealed that the idea which started in the USA has in later periods gotten significant devotion with the state legislators in both industrialised and emerging economics, global corporations, the government, and scholars. According to (Voinea et al., 2019), no serious contract between spectators on the sudden rise of the CSR concept it has been accelerated by the expanding request by the general public to regulate the rising influence and in some cases unreliable conducts of enterprises that are some of the time naturally post as an extraordinary risk to economic and social development, as well as nationwide sway.

Likewise, the (WBCSD, 2000) explained CSR as 'the consistent promise by corporate to act morally as well as add to fiscal growth while advancing the value of the lifespan of the employees and their relations and the host residential area and people at large.' 


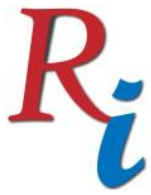

\section{Asia Proceedings of Social Sciences (APSS) \\ www.readersinsight.net/APSS}

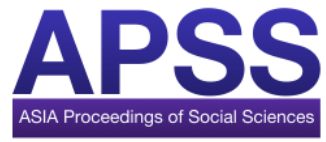

(Carroll, 1999) Within the 1980s, as he stated, some other theoretic topics were included in the theory itself, plus shareholders theory, corporate morals theory and corporate social performance. In the definitional advancement that happened in the $90 \mathrm{~s}$, these other topics took a front step in the appearance of CSR, (Sahut et al., 2019) and every successive meaning was controlled by the shareholder and social method, with the appreciation of economic, social, and ecological matters as the elementary mechanisms of obligation.

\section{Findings}

The review also noticed that instead of being a restricted subfield of administration or commerce researchers, concern in CSR has extended to other fields, such as legislative issues, (Knudsen et al.,2015), financial matters, (Beddewela, 2019)."Maintained that "using the tenets of the concept to the analysis of CSR permits for a much better comprehension of corporate obligations in two main features: the variety of CSR and the actions of CSR".

The review shows that the concept offers impressive tenets for comprehending and clarifying how and why CSR adopts diverse shapes in diverse nations. It furthermore gives highlights into why this idea is presently share and portion of corporate exercises in almost every major nation worldwide. In terms of institutional functions, the study demonstrates that for the analysis of CSR, the concepts thus contribute to different stages. It is rational to contend that even after 30 years of study into CSR, normally the generic meaning of the idea is nevertheless salient (Schoeneborn et al., 2020). The review according to (Scott, 2019), indicates that there are diverse administrative frameworks within the business ordinance scene.

\section{References}

Arli, D. I., \& Lasmono, H. K. (2010). Consumers' perception of corporate social responsibility in a developing country. International Journal of Consumer Studies, 34(1), 46-51.

Beddewela, E. (2019). Managing corporate community responsibility in multinational corporations: Resolving institutional duality. Long Range Planning, 52(6), 101911.

Carroll, A. B. (1999). Corporate social responsibility: Evolution of a definitional construct. Business \& Society, 38(3), 268-295.

Matten, D., \& Moon, J. (2020). Reflections on the 2018 Decade Award: The Meaning and Dynamics of Corporate Social Responsibility. Academy of management Review, 45(1), 7-28.

Sahut, J.-M., Peris-Ortiz, M., \& Teulon, F. (2019). Corporate social responsibility and governance. Journal of Management and Governance, 23(4), 901-912. 


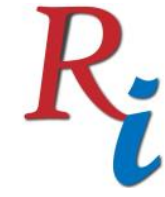

\section{Asia Proceedings of Social Sciences (APSS) \\ www.readersinsight.net/APSS}

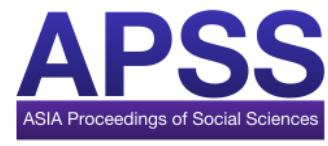

Schoeneborn, D., Morsing, M., \& Crane, A. (2020). Formative perspectives on the relation between CSR communication and CSR practices: Pathways for walking, talking, and $\mathrm{t}(\mathrm{w})$ alking. Business \& Society, 59(1), 5-33.

Scott, C. (2019). The Democratic Challenges of Effective Private Regulation and Enforcement. In Senden L., de Cock Buning M.(eds.). Private Regulation and Enforcement in the EU: Finding the Right Balance from a Citizen's Perspective: Hart Publishing.

Sepúlveda, S., Diéguez, M., Farías, G., \& Cachero, C. (2019). Systematic literature review protocol. Learning-outcomes and teaching-learning process: a Bloom's taxonomy perspective. arXiv preprint arXiv:1911.09489.

Uzo, U., \& Shittu, O. (2019). Nigeria's Informal Economy, Social Responsibility and Sustainable Development. Corporate Social Responsibility in Developing and Emerging Markets: Institutions, Actors and Sustainable Development, 191.

Voinea, C. L., Fratostiteanu, C., \& Romein, B. (2019). The Influence of Governance and Ownership on CSR Practices in Romania. European Journal of Sustainable Development, 8(3), 313-313. 